\title{
NOTE ON LADLE BRICK ${ }^{1}$
}

\author{
BY D. A. Moulton
}

ABSTRACT

Review of Literature on Ladle Brick.-(1) American ladle in which it is stated no chemical reactions occur; (2) English ladle in which four or five chemical reactions occur simultaneously.

Fusion Point of Ladle Brick ranging from cones 17 to 30 depending on behavior of clay at temperatures below the fusion point.

Process of Manufacture.-Two processes, namely dry press and stiff-mud with preference for dry press. Modification of standard refractories is suggested.

\section{Review of Literature on Subject}

Refractory work $^{2}$ in a steel department begins with the lining of ladles used in transporting the molten metal from the blast furnace to a metal mixer, Bessemer converter, or to open hearth furnaces. A practical lining for such ladles consists of brick covered with a rammed mud cake made of six parts fire-brick grog, two parts clay, and two parts silica stone. This cake will last forty-eight hours continuous use, possibly longer, and comes out with the "skull." The temperature of blast furnace iron running into ladle is $2850^{\circ} \mathrm{F}$, hence the lining must be refractory enough to easily withstand this temperature.

A charge ${ }^{3}$ of forty tons of $\mathrm{H}$. E. shell steel poured into a ladle with two casting nozzles left only fifty-six pounds or less of "skull" when the ladle was emptied. This ladle was unevenly preheated, and four or five reactions may be going on simultaneously in such a ladle, these reactions being exaggerated by the unevenly preheated ladle.

The reactions are oxidation, deoxidation, colloidal segregation, cooling, and definite change of phase (skull formation). This steel contained oxygen when tapped and had oxygen added to it by the ladle lining, so a test was run to determine the quantity of gas evolved by the ladle brick and the quality of the gas, when the sample was at red heat in vacuum by a Sprengel pump.

The following is chemical analysis of this brick lining:

Loss on ignition....... 0.20

$\mathrm{SiO}_{2} \ldots \ldots \ldots \ldots \ldots \ldots \ldots$ 54.00 One hundred grams of this brick

$\mathrm{Al}_{2} \mathrm{O}_{3} \ldots \ldots \ldots \ldots \ldots \ldots \ldots . \ldots \ldots$ sample only gave off $2.45 \mathrm{cc}$. of

$\mathrm{Fe}_{2} \mathrm{O}_{3} \ldots \ldots \ldots \ldots \ldots \ldots .5 .28$ gas at $767 \mathrm{~mm}$. at $15^{\circ} \mathrm{C}$.

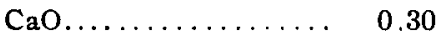

$\mathrm{KNaO} \ldots \ldots \ldots \ldots \ldots \ldots$

'St. Louis Meeting, March 1, 1922.

2 "Refractory L,inings and Materials" by J. W. Haulman, Blast Furnace and Steel Plant, 5, 159 (1917).

"Properties of Refractories Used in Steel Production" by Allene Reynolds, Trans. Ceram. Soc. (Eng.), 17, 385 (1917-18). 
Clays Used in Ladle Bricks. - The ladle bricks made in this country are manufactured from No. 2 and No. 3 fire clays of which following analyses are typical.

\begin{tabular}{|c|c|c|c|c|c|c|}
\hline & $\begin{array}{l}\text { New Brighton } \\
\text { Lower Kittaning }\end{array}$ & New Jersey & $\begin{array}{l}\text { Aetna Mine } \\
\text { W. Va. }\end{array}$ & Kentucky & Iowa & English \\
\hline $\mathrm{SiO}_{2}$ & 62.89 & 67.26 & 57.52 & 60.52 & 62.49 & 61.88 \\
\hline $\mathrm{Al}_{2} \mathrm{O}_{3}$ & 21.49 & 23.36 & 21.76 & 20.99 & 24.42 & 22.37 \\
\hline $\mathrm{Fe}_{2} \mathrm{O}_{\mathrm{a}}$ & 1.81 & 1.63 & 3.41 & 3.41 & 1.45 & 3.00 \\
\hline $\mathrm{CaO}$ & 0.38 & 0.25 & 0.60 & 0.21 & 0.29 & 0.32 \\
\hline $\mathrm{MgO}$ & 0.56 & & 0.88 & 0.14 & 0.08 & 0.44 \\
\hline Alkalies & 0.29 & 0.65 & 3.60 & 2.85 & 2.41 & $\begin{array}{rr}\mathrm{NaO} & 0.36 \\
\mathrm{KO} & 1.42\end{array}$ \\
\hline $\mathrm{TiO}_{2}$ & 1.03 & & 0.83 & 1.10 & 1.19 & 1.14 \\
\hline Ignition & 13.76 & 6.94 & 8.13 & 9.83 & 7.35 & 8.72 \\
\hline
\end{tabular}

The range of fusion of clays used in making ladle brick and of the brick themselves runs from cone 17 to cone 30 . The picture illustrates a dry press

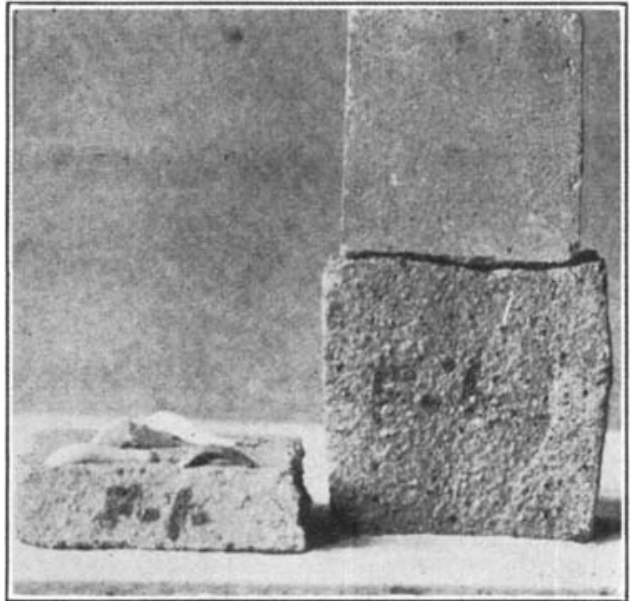

FIG. 1. ladle brick, the upper half of which was not put into fusion furnace. The lower half was subjected to a heat treatment which caused a cone made from the same brick to fuse down. The brick was swelled some and had cracked.

This brick in practice is giving about eleven heats with a mild steel low in carbon, using loose soil in bottom of ladle each time it is filled. ${ }^{1}$ As high as 1000 heats can be obtained with a brick lining when the rammed clay lining is used to protect the brick.

The best ladle bricks have a fusion point of cone 26 and give 15 to 20 heats and are made without addition of any sandy material.

\section{Methods of Manufacture}

Ladle brick are made by both the stiff-mud and the dry-press process. The dry-press brick have given much better results in ladles.

Testing of Ladle Brick. - It is found that the standard tests for refractory bricks are too severe for ladle bricks and especially is this true of

${ }^{1}$ Information furnished by H. V. Smallwood, Purchasing Agent, Whitaker-Glessner Co., Portsmouth, $\mathrm{O}$. 
the slag test. The slag test, calling for exposure of five sides of the brick to the temperature of molton slag badly overfires the brick. The following heat treatment seemed to be best for slag test, using open hearth slags: Bring the kiln up to $2240^{\circ} \mathrm{F}$, then put the brick into furnace; when $2350^{\circ} \mathrm{F}$ is obtained put slag onto the brick; hold at $2350^{\circ} \mathrm{F}$ for one-half hour. This produces a penetration averaging 0.15 inches for brick made of clay itself (mostly chemical solution), while in brick having an addition of sandy material, the penetration averages 0.30 inches, consisting of less chemical solution and more mechanical penetration filling very small crevices in the brick.

In testing with copper slags containing some metallic copper, the temperature of $2150^{\circ} \mathrm{F}$ is used, and the slag added and held at this temperature for three hours.

This copper test gives a penetration of 0.06 inch for brick of clay itself (mostly chemical solution), and 0.36 penetration in brick using sand rock with clay, this being mostly mechanical penetration.

The load test is also too severe for this class of brick.

The usual spalling test employed in testing high grade refractories, (cooling rapidly in water) is too severe. An air blast on hot end of brick gives comparative results and permits of grading of ladle brick in regard to ability to withstand spalling action.

Since large quantities of ladle brick are used every year, it is desirable to have special specified test for this particular type of refractories.

Iowa Srate Coll,ege

AMEs, IowA 